In cooperation with the U.S. Fish and Wildlife Service, Nebraska Game and Parks Commission, and The Nature Conservancy

\title{
Land Capability Potential Index (LCPI) for the Lower Missouri River Valley
}

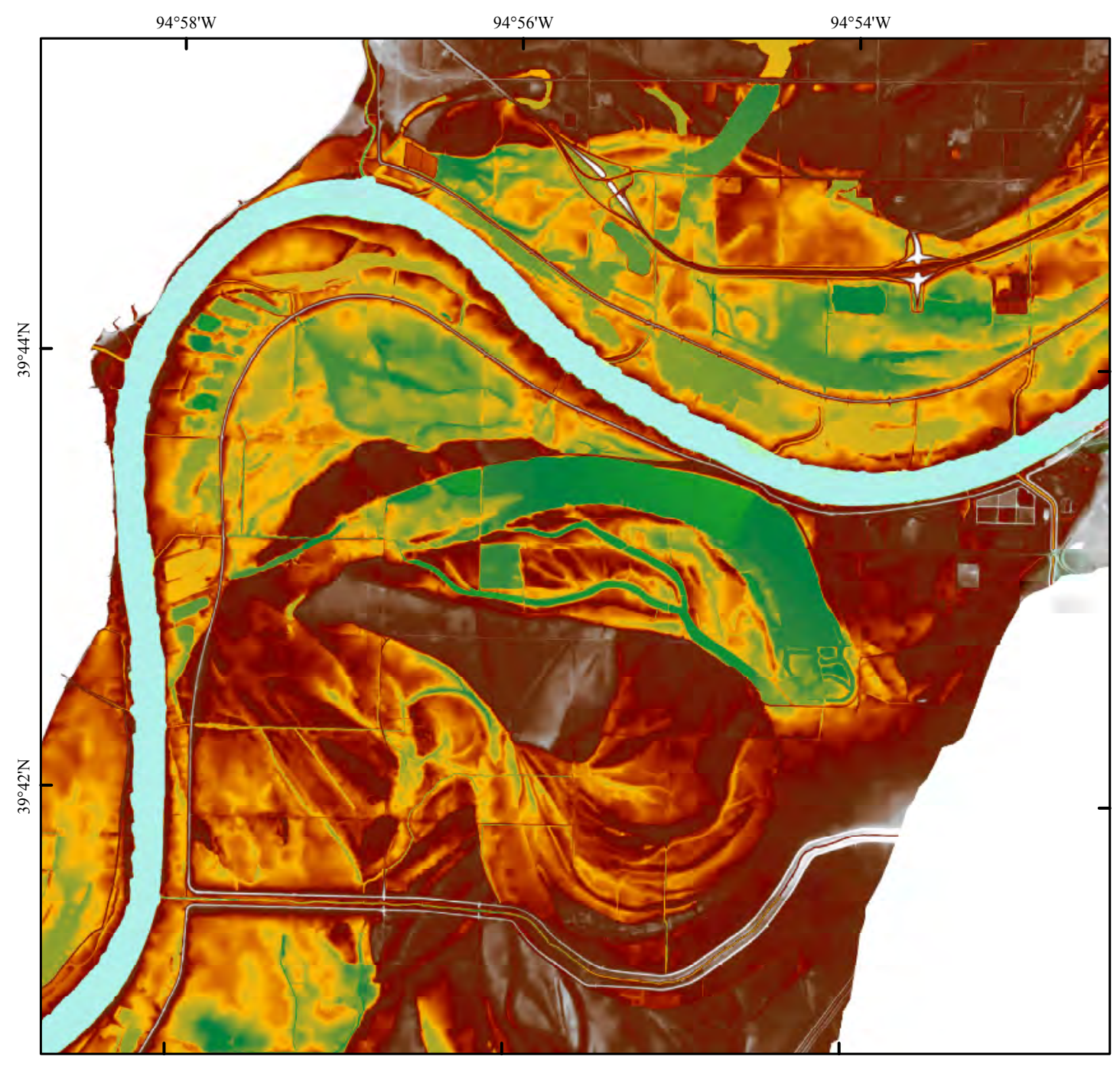

Scientific Investigations Report 2007-5256 
Cover graphic. Land-surface elevation relative to the construction reference plane, Missouri River Valley near St. Joseph, Missouri. 


\section{Land Capability Potential Index (LCPI) for the Lower Missouri River Valley}

By Robert B. Jacobson, Kimberly A. Chojnacki, Joanna M. Reuter

In cooperation with the U.S. Fish and Wildlife Service, Nebraska Game and Parks Commission, and The Nature Conservancy

Scientific Investigations Report 2007-5256 


\section{U.S. Department of the Interior DIRK KEMPTHORNE, Secretary}

\section{U.S. Geological Survey \\ Mark D. Myers, Director}

\section{U.S. Geological Survey, Reston, Virginia: 2007}

For product and ordering information:

World Wide Web: http://www.usgs.gov/pubprod

Telephone: 1-888-ASK-USGS

For more information on the USGS--the Federal source for science about the Earth, its natural and living resources, natural hazards, and the environment:

World Wide Web: http://www.usgs.gov

Telephone: 1-888-ASK-USGS

Any use of trade, product, or firm names is for descriptive purposes only and does not imply endorsement by the U.S. Government.

Although this report is in the public domain, permission must be secured from the individual copyright owners to reproduce any copyrighted materials contained within this report.

Suggested citation:

Jacobson, R.B., Chojnacki, K.A., and Reuter, J.M., 2007, Land Capability Potential Index (LCPI) for the Lower Missouri River Valley: U.S. Geological Survey Scientific Investigations Report 2007-5256, 19 p. 


\section{Contents}

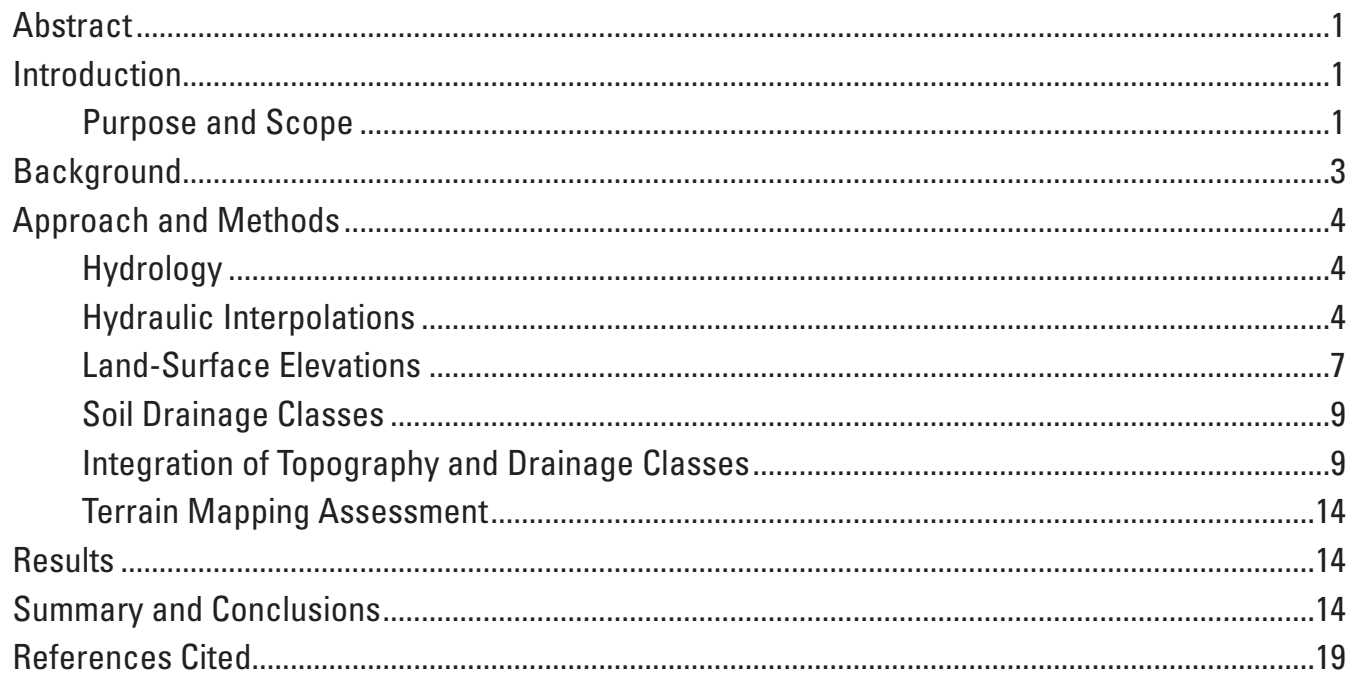

\section{Figures}

1. Map showing the Lower Missouri River (LMOR), Gavins Point Dam to St. Louis, Missouri.

2. Duration hydrographs showing variation with downstream location on the Lower Missouri River ...

3. Graph showing general degradation trends, Lower Missouri River, shown as stage changes from 1954 to mid-1990's, for given discharges.

4. Conceptual classification of the Lower Missouri River valley-bottom landforms and relations to hydrology

5. Diagram showing architecture of the Lower Missouri River valley bottom .....................6

6. Long profiles of water-surface elevations associated with flow exceedances and floods in study section

7-8. Maps showing-

7. Part of the Lower Missouri River valley bottom near St. Joseph, Missouri, showing the topographic detail available from the elevation dataset.....

8. Soil-drainage classes of a part of the Lower Missouri River valley bottom near St. Joseph, Missouri

9. Graph showing an example illustrating the potential effect of "overmapping" of flood areas by extrapolating flood levels across the valley bottom

10-11. Maps showing-

10. Relative flood frequency of a part of the Lower Missouri River valley bottom near St. Joseph, Missouri, estimated from intersecting water-surface profiles with valley-bottom elevations.

11. Land Capability Potential Index classes calculated from integrating wetness and retention classes, for a part of the Lower Missouri River valley bottom near St. Joseph, Missouri . 
12-14. Maps showing-

12. Two-year flooding reference elevation showing regional variation of wetness potential as a result of channel aggradation and degradation

13. Land-surface elevation relative to the Construction Reference Plane (CRP)........17

14. Terrain classes for a part of the Lower Missouri River valley bottom near St. Joseph, Missouri.

\section{Tables}

1A. Hydrologic data for calculations of Land Capability Potential Index (LCPI), exceedances

1B. Hydrologic data for calculations of Land Capability Potential Index (LCPI), floods .........7

2. Aggregation of wetness and soil drainage classes into tentative Land Capability Potential Index (LCPI) classes. 


\section{Conversion Factors}

\section{Inch/Pound to SI}

\begin{tabular}{lcc}
\hline Multiply & By & To obtain \\
\hline mile $(\mathrm{mi})$ & Length & \\
\hline & 1.609 & kilometer $(\mathrm{km})$ \\
\hline cubic foot per second $\left(\mathrm{ft}^{3} / \mathrm{s}\right)$ & Flow rate & \\
\hline
\end{tabular}

\section{SI to Inch/Pound}

\begin{tabular}{lcl}
\hline \multicolumn{1}{c}{ Multiply } & By & \multicolumn{1}{c}{ To obtain } \\
\hline millimeter $(\mathrm{mm})$ & Length & \\
meter $(\mathrm{m})$ & 0.03937 & inch (in.) \\
kilometer $(\mathrm{km})$ & 3.281 & foot $(\mathrm{ft})$ \\
meter $(\mathrm{m})$ & 0.6214 & mile $(\mathrm{mi})$ \\
& 1.094 & yard $(\mathrm{yd})$ \\
\hline square meter $\left(\mathrm{m}^{2}\right)$ & Area & \\
square kilometer $\left(\mathrm{km}^{2}\right)$ & 0.0002471 & acre \\
square meter $\left(\mathrm{m}^{2}\right)$ & 247.1 & acre \\
hectare $($ ha) & 10.76 & square foot $\left(\mathrm{ft}^{2}\right)$ \\
square kilometer $\left(\mathrm{km}^{2}\right)$ & 0.003861 & square mile $\left(\mathrm{mi}^{2}\right)$ \\
& 0.3861 & square mile $\left(\mathrm{mi}^{2}\right)$ \\
\hline cubic kilometer $\left(\mathrm{km}^{2}\right)$ & Volume & \\
\hline & 810713.2 & Acre-foot $(\mathrm{ac}-\mathrm{ft})$ \\
\hline cubic meter per second $\left(\mathrm{m}^{3} / \mathrm{s}\right)$ & Flow rate & \\
\hline
\end{tabular}

For consistency with common usage, distances along the Missouri River are given in river miles upstream from St. Louis, Missouri.

Vertical coordinate information is referenced to the National Geodetic Vertical Datum of 1929 (NGVD 29).

Horizontal coordinate information is referenced to the North American Datum of 1983 (NAD 83).

Altitude, as used in this report, refers to distance above the vertical datum. 



\title{
Land Capability Potential Index (LCPI) for the Lower Missouri River Valley
}

\author{
Robert B. Jacobson, Kimberly A. Chojnacki, Joanna M. Reuter
}

\section{Abstract}

The Land Capability Potential Index (LCPI) was developed to serve as a relatively coarse-scale index to delineate broad land capability classes in the valley of the Lower Missouri River. The index integrates fundamental factors that determine suitability of land for various uses, and may provide a useful mechanism to guide land-management decisions. The LCPI was constructed from integration of hydrology, hydraulics, land-surface elevations, and soil permeability (or saturated hydraulic conductivity) datasets for an area of the Lower Missouri River, river miles 423-670. The LCPI estimates relative wetness based on intersecting water-surface elevations, interpolated from measurements or calculated from hydraulic models, with a high-resolution land-surface elevation dataset. The potential for wet areas to retain or drain water is assessed using soil-drainage classes that are estimated from saturated hydraulic conductivity of surface soils. Terrain mapping that delineates areas with convex, concave, and flat parts of the landscape provides another means to assess tendency of landscape patches to retain surface water.

\section{Introduction}

The potential for valley-bottom lands to support various land uses - agricultural, urban, recreational, or ecologicalprimarily depends on how surface- and ground-water interact with land-surface elevations. These interactions are mediated by soils and underlying surficial geologic materials that affect drainage or retention of water. The distribution and retention of water are the factors that are most likely to be manipulated to achieve traditional social uses or ecological restoration of valley-bottom lands.

From the late 1980's to the present (2007), the channel, flood plain, and adjacent alluvial terraces of the Lower Missouri River (LMOR; fig. 1) have been increasingly subject to changes in use as public perceptions and values have changed. In particular, recognition of loss of riverine habitat, listing of threatened or endangered fish and bird species (U.S. Fish and Wildlife Service, 2003), increases in opportunities for recre- ational uses, and flooding of the LMOR 1993-97 (Jacobson, 2006), have created pressure for conversion of lands from agriculture to conservation purposes. Public expenditures for valley-bottom land conversion have been substantial. For example, between 1986 and 2004, the U.S. Army Corps of Engineers (USACE) spent nearly \$100 million in land acquisition and rehabilitation; the total goal under the USACE Mitigation Program is 118,650 acres (U.S. Army Corps of Engineers, 2004a). In 1994, the U.S. Fish and Wildlife Service (USFWS) created the Big Muddy National Fish and Wildlife Refuge to acquire 60,000 acres of Missouri River bottom land between St. Louis and Kansas City, Missouri, for habitat rehabilitation (Jacobson, 2006). Notwithstanding this large public investment in land conversion, there exists no systematic classification of Missouri River valley-bottom land capability to guide acquisition and management efforts.

The LCPI presented in this report was developed to address the need for a systematic classification of LMOR bottom lands. The index was developed in partnership with the USFWS Rainwater Basin Joint Venture, Nebraska Game and Parks Commission, and The Nature Conservancy's Missouri River Program.

\section{Purpose and Scope}

The purpose of this report is to document methods used in creating a Land Capability Potential Index (LCPI) for part of the LMOR valley bottom in Nebraska, Iowa, Kansas, and Missouri (fig. 1). The LCPI is intended to provide a simple, systematic index of relative flooding and wetness potential of the Missouri River valley-bottom lands. The LCPI is created from available land-surface elevation, hydrologic, hydraulic, and soils datasets. These datasets have inherent limitations and the LCPI should not be used for site-specific assessments. However, at the scale of tens to hundreds of kilometers, the LCPI provides an index that can be used for assessing relative land-use capability. The intent behind development of the LCPI is to provide a method that landowners and public agencies can use to assess the inherent, physically determined capabilities of valley-bottom lands. 


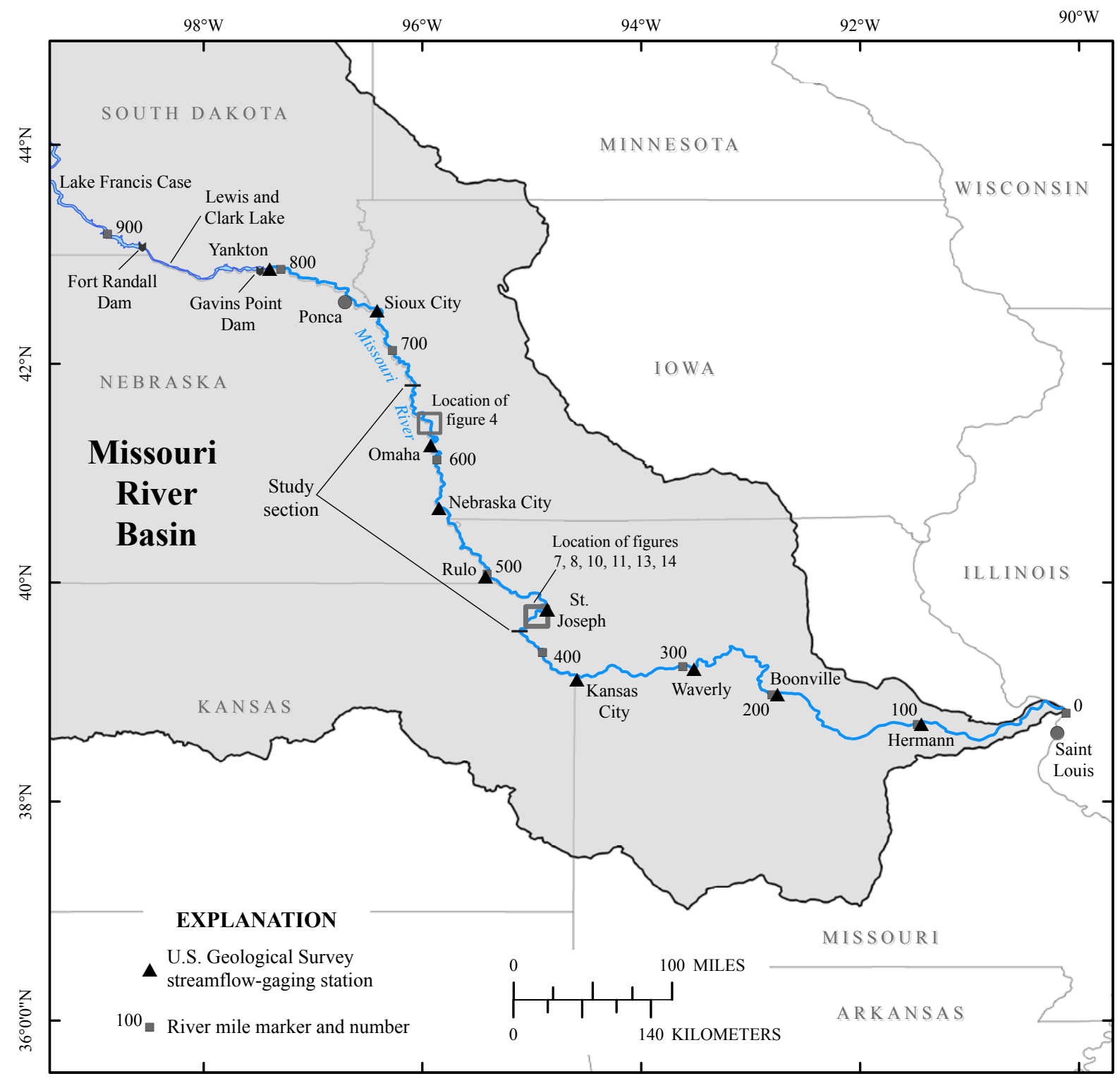

Base from U.S. Geological Survey digital data, 2002, 1:2,000,000 Geographic coordinate system, North American Datum 1983

Figure 1. Lower Missouri River (LMOR), Gavins Point Dam to St. Louis, Missouri. 


\section{Background}

The Missouri River has been dammed at Gavins Point, South Dakota, since 1957. Regulation of the Missouri River Reservoir System for flood control, navigation, and power production has resulted in substantial change to intra- and interannual variability in discharges, with the most profound changes being recorded at the long-term U.S. Geological Survey (USGS) streamflow-gaging station at Sioux City, Iowa, 80 miles downstream from the dam (fig. 2). The degree of hydrologic alteration decreases in the downstream direction as less-regulated tributaries add flow to the Missouri River.

From Sioux City, Iowa, to St. Louis, Missouri, the channel of the Missouri River has been engineered to support a self-dredging channel. Narrowing of the channel, stabilization of the banks of the accreted land, and construction of levees have resulted in substantial losses of valley-bottom habitats. The USACE has estimated that the Bank Stabilization and Navigation Project resulted in loss of as much as 400 square kilometers $\left(\mathrm{km}^{2}\right)$ of aquatic habitat and $274 \mathrm{~km}^{2}$ of terrestrial habitat (sandbars and low-lying lands) within the active channel; loss of terrestrial habitat within the meander belt is as much as $1,400 \mathrm{~km}^{2}$ (U.S. Army Corps of Engineers, 2004c).

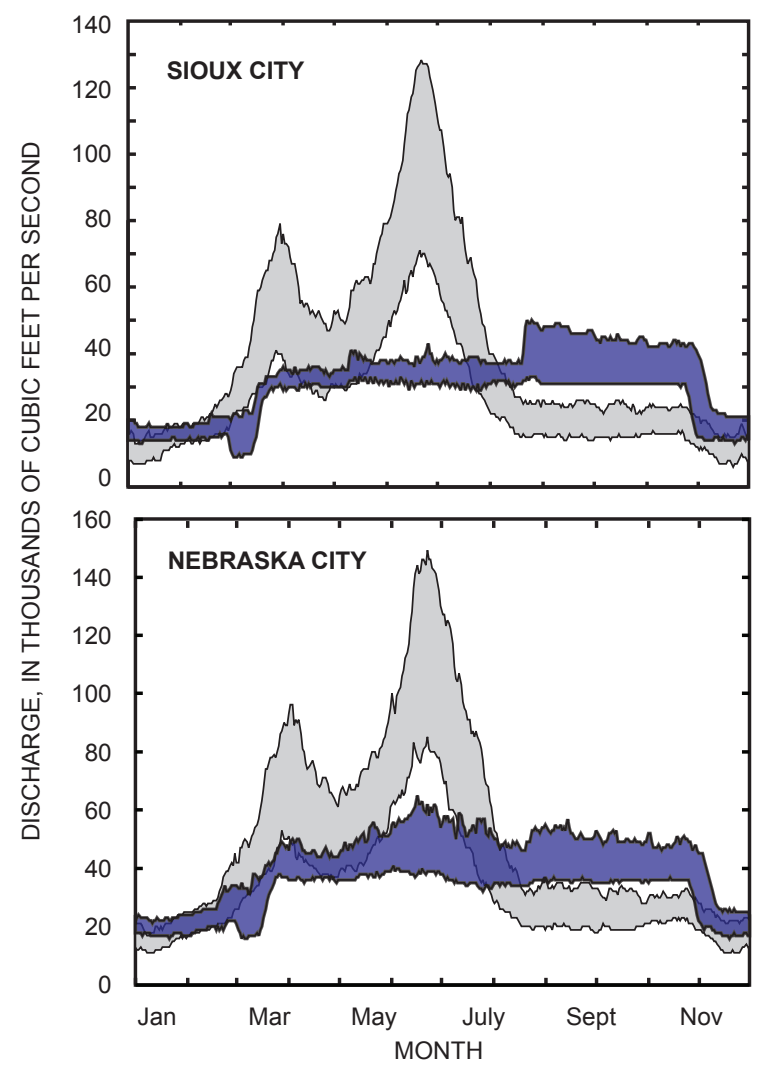

Another effect of the dams has been substantial diminishment of sediment load because of sedimentation in the reservoirs. The channel has incised 3-5 meters (m) in the first 100 kilometers (km) downstream from Gavins Point Dam (fig. 3). Channel elevations generally recover near Omaha, but further downstream, the reach around Kansas City is degrading substantially (U.S. Army Corps of Engineers, 2004b). Increased stages for large discharges have been attributed to channel constriction by revetments and levees, whereas channel degradation has been attributed to sediment deficits and constriction by wing dikes (Pinter and others, 2002). The downstream most $400 \mathrm{~km}$ is characterized by modest channel incision, resulting in decreased stages for low discharges. The section of the river downstream from Omaha and upstream from St. Joseph, Missouri is aggrading (fig. 3).

Conceptually, the Missouri River valley bottom is composed of active channel, meander belt (or flood plain), alluvial terraces, and bordering colluvial landforms downslope of bluffs (fig. 4). Together, we refer to these landforms as the valley bottom. The active channel is that part of the valley bottom that contains most of the mainstem discharge and is characterized by the bed, sandbars, and banks of the river. The meander belt is that part of the land surface that the river channel has occupied and deposited during the Late Holocene. Because of its relatively recent deposition, the meander belt retains some

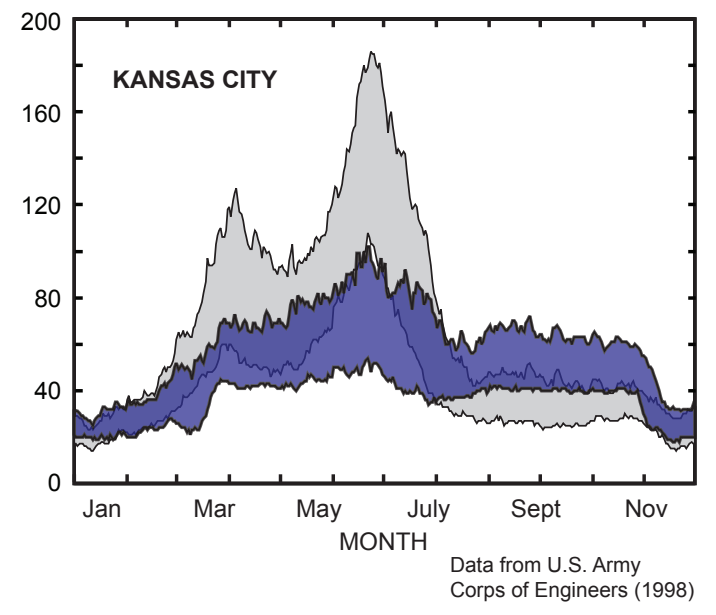

EXPLANATION

Daily flow exceedances (25-75 percent)

Reference duration hydrogaph

Current water control plan duration hdrograph

Figure 2. Duration hydrographs showing variation with downstream location on the Lower Missouri River. 


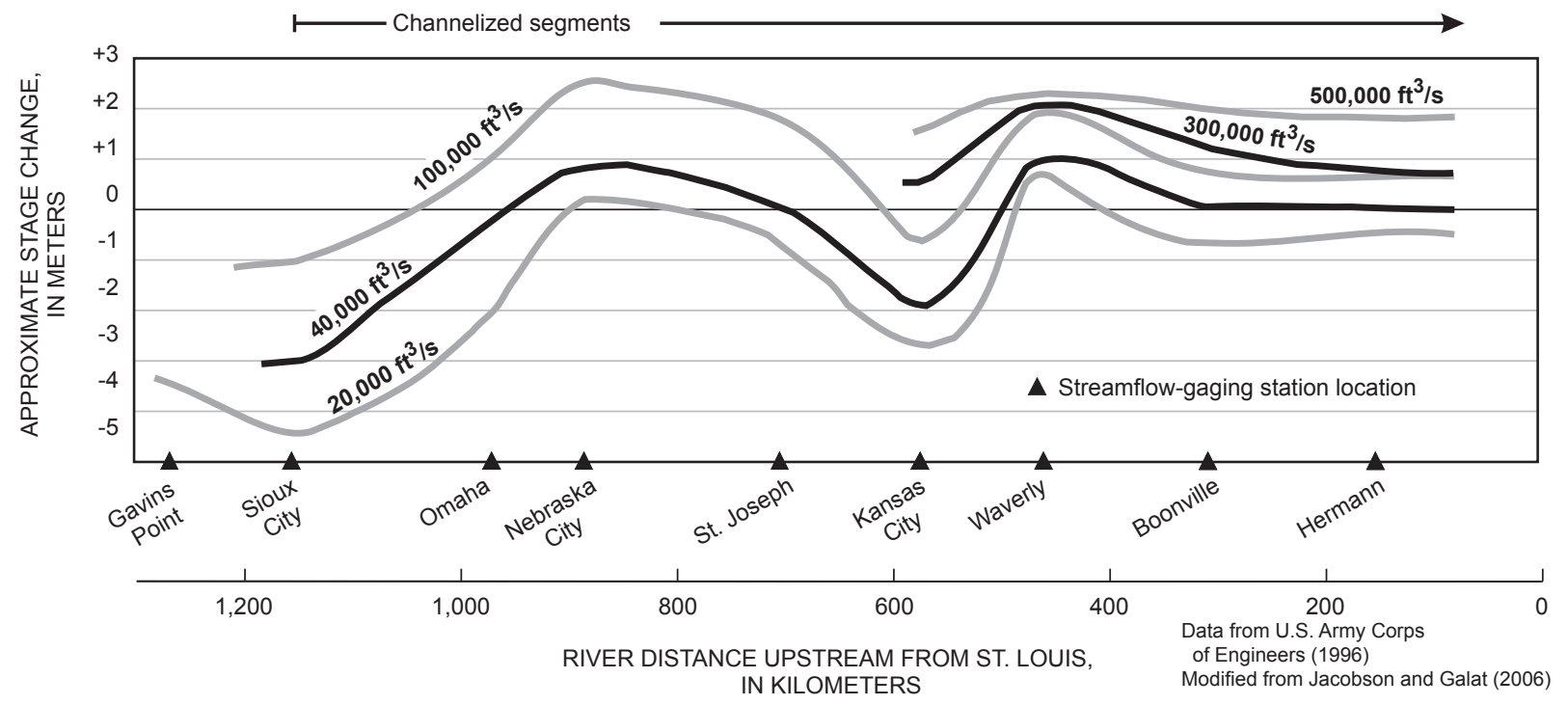

Figure 3. General degradation trends, Lower Missouri River, shown as stage changes from 1954 to mid-1990's, for given discharges.

of the original ridge and swale topography, although is has been altered to various extents through farming, road construction, and ditching.

The ridge and swale topography of the meander belt results in juxtaposition of parts of the landscape with differing potential for flooding by surface water. In addition, ridge and swale topography is indicative of underlying surficial geology (fig. 5). The ridges mainly are remnants of point bars and tend to be sandy, whereas the swales are infilled channels, which tend to be composed of silt and clay sediments (Holbrook and others, 2006). The meander belt is flooded relatively frequently. For the purposes of this report, the meander belt is delineated by areas that are subject to flooding with a probability of once per year to 1/100 per year (that is, the 100-year recurrence flood plain). Bordering terraces and colluvial land forms flood much less frequently.

\section{Approach and Methods}

The following sections outline the steps in developing the LCPI, including the development of hydrology, hydraulics, land-surface elevation, and soil drainage class datasets. All these datasets are readily available on the LMOR from existing sources.

\section{Hydrology}

Hydrologic assessments were addressed in two ways. For relatively frequent flows, flow duration analyses were performed at USGS streamflow-gaging stations on the LMOR (table 1A) using the period of record 1967 to 2006 (post reservoir filling). Daily discharges equaled or exceeded 1, 2, 5, and 10 percent of the time were calculated from the flow records at each gaging station and associated with a water-surface elevation at each gage site based on the stage-discharge rating curve and gage datum.

The second source of hydrologic information was the USACE Upper Mississippi River System Flow Frequency Study (U.S. Army Corps of Engineers, 2004d), which calculated flood frequencies for each of the USGS streamflow-gaging stations using standardized methods. These calculations provided discharges for the $1,2,5,10,25,50,100,250$, and 500 -year recurrence floods (equivalent to annual probabilities of $100,50,20,10,4,2,1,0.4$ and 0.2 percent) under current (2007) reservoir regulation (table 1B).

\section{Hydraulic Interpolations}

To be useful in habitat assessments, flow quantiles determined at USGS streamflow-gaging stations need to be interpolated or extrapolated along the river to reaches of interest. Because hydraulic roughness, cross-sectional channel morphology, and channel slope vary along a river, the stagedischarge relation also varies. Hence, it is not hydraulically valid to interpolate water-surface elevations for given flow quantiles from gage to gage.

The Upper Mississippi River System Flow Frequency Study (UMRSFFS) addressed hydraulics by explicitly modeling flows using a 1-dimensional unsteady hydraulic model (U.S. Army Corps of Engineers, 2004d). These models were calibrated to reproduce water-surface elevations for the consid- 


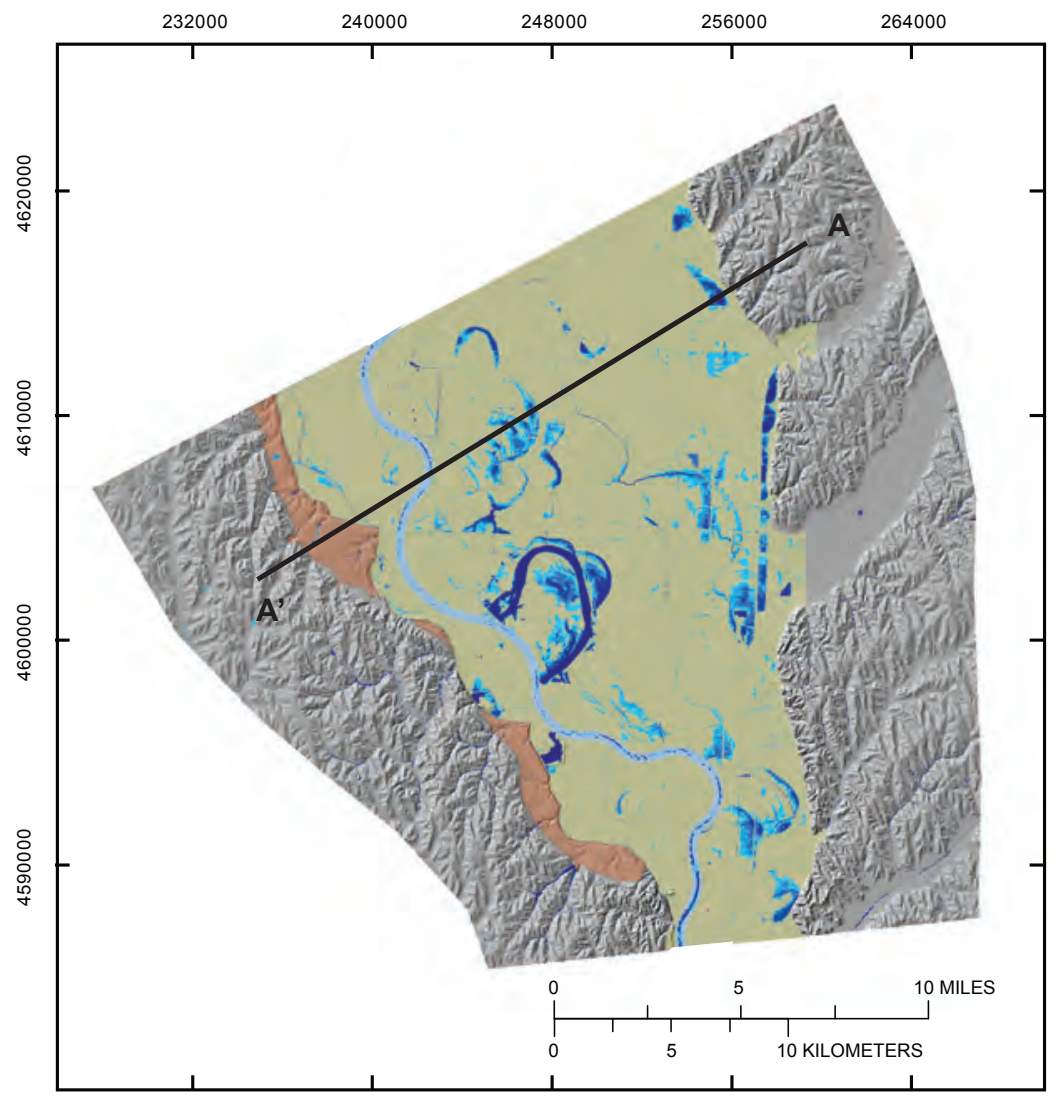

\section{EXPLANATION}

Active channel-River channel and active sandbars, margins at elevations less than 2-year recurrence flood

Meander belt-Historical and late-Holocene meander belt, characterized by abundant ridgeswale topography, ox-bow lakes, and relatively undeveloped soils

Terraces-Remnants on Pleistocene terraces, greater than 10 meters above modern river

Blufflands-Areas along the valley margin, characterized by steep slopes, colluvial deposits and loess soils

Topographic depressions-Non-drained depressions in meander belt, mostly resulting from natural ridge and swale topography

\section{$A-A^{\prime}$ Trace of section}

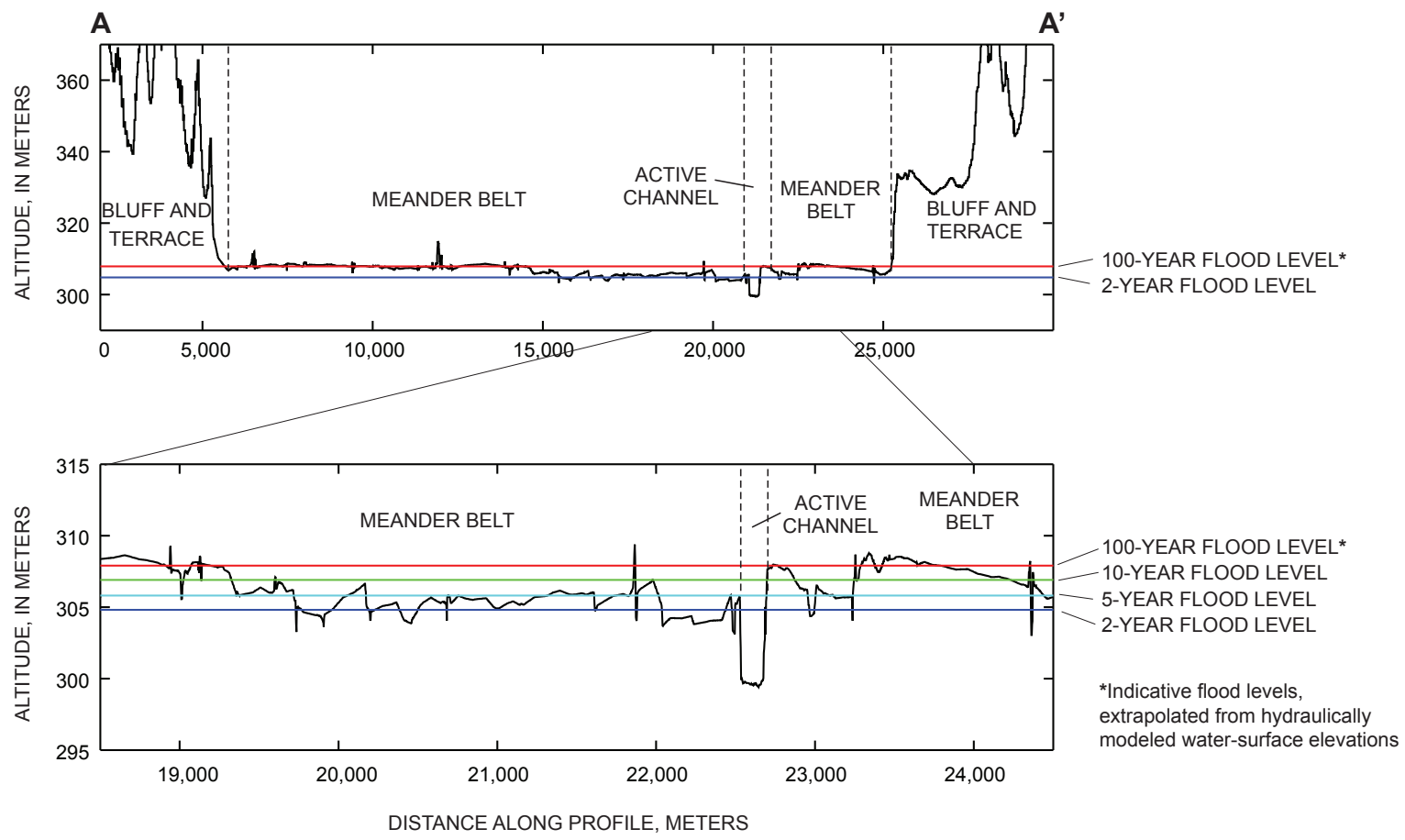

Figure 4. Conceptual classification of the Lower Missouri River valley-bottom landforms and relations to hydrology. Example taken from near DeSoto Lake, lowa, river mile 630-655. *Indicative flood levels, extrapolated from hydraulically modeled water-surface elevations. 


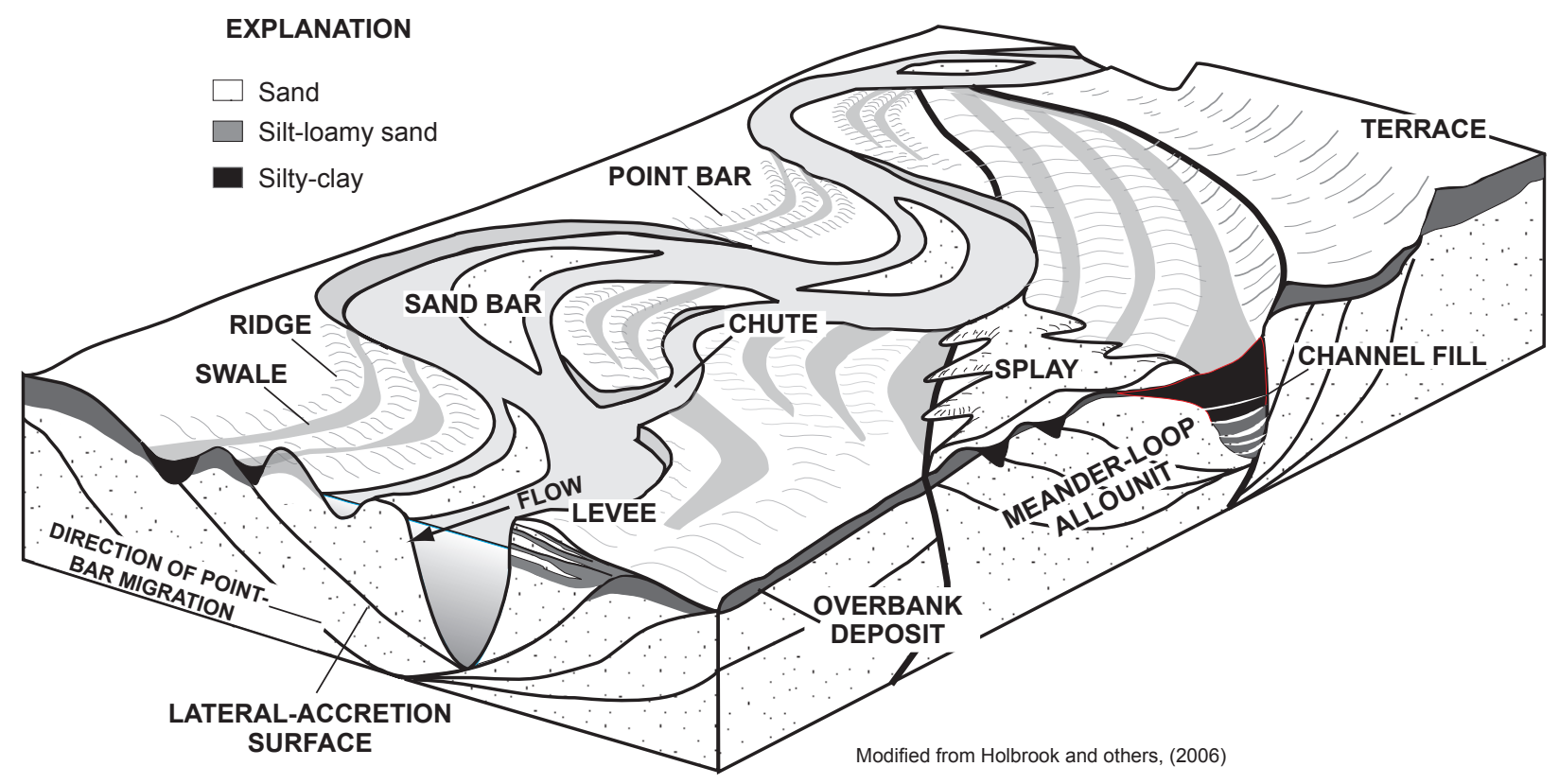

Figure 5. Architecture of the Lower Missouri River valley bottom. Meander loops are formed by lateral migration of pointbars and smaller lateral bars that are attached to the channel boundary on the inside of meander loops. Lateral migration occurs in stages, producing a series of lateral-accretion surfaces, which manifest on the surface as ridges and swales oriented sub-parallel to the river channel. Point bars tend to decrease in grain size upward from sand to fine gravel at the base to silt and clay at the top. Channel fills record sedimentation in channels that have been abandoned from the active flow by local meander-bend cut off, or shifting of the entire channel to a new location on the flood plain (avulsion). Channel fills are generally floored with the coarse material typical of the bed load carried by the river. Channel fills are recognized as long arcuate and straight trends of low topography with widths equal to or less than the forming channel.

Table 1A. Hydrologic data for calculations of Land Capability Potential Index (LCPI), exceedances.

[ft 3 s, cubic feet per second; USACE, U.S. Army Corps of Engineers]

\begin{tabular}{clrrrr}
\hline $\begin{array}{c}\text { U.S. Geological } \\
\text { Survey } \\
\text { streamflow- } \\
\text { gaging station }\end{array}$ & \multicolumn{1}{c}{ Location } & \multicolumn{3}{c}{ Flows at indicated exceedances, $\mathbf{f t}^{\mathbf{3}} / \mathbf{s}^{\mathbf{1}}$} \\
\cline { 3 - 6 } & & $\mathbf{1 0 \text { percent }}$ & $\mathbf{5}$ percent & 2 percent & 1 percent \\
\hline 06934500 & Hermann, Missouri & 169,000 & 221,000 & 276,000 & 328,000 \\
06909000 & Boonville, Missouri & 126,000 & 166,000 & 217,000 & 252,000 \\
06895500 & Waverly, Missouri & 100,000 & 125,000 & 156,000 & 186,000 \\
06893000 & Kansas City, Missouri & 96,060 & 118,000 & 148,000 & 176,000 \\
06818000 & St. Joseph, Missouri & 74,860 & 89,700 & 113,120 & 128,000 \\
06813500 & Rulo, Nebraska & 69,000 & 80,000 & 99,900 & 112,000 \\
06807000 & Nebraska City, Nebraska & 63,760 & 71,800 & 84,900 & 97,500 \\
06610000 & Omaha, Nebraska & 54,600 & 61,800 & 70,900 & 76,756 \\
06601200 & Decatur, Nebraska & 48,900 & 60,100 & 69,436 & 73,034 \\
06486000 & Sioux City, Iowa & 48,600 & 55,100 & 63,612 & 68,212 \\
\hline
\end{tabular}

${ }^{1}$ Calculated from U.S. Geological Survey streamflow-gaging station records, 1967-2006. 
Table 1B. Hydrologic data for calculations of Land Capability Potential Index (LCPI), floods.

[ft $3 / \mathrm{s}$, cubic feet per second; \%, percent; USACE, U.S. Army Corps of Engineers]

\begin{tabular}{|c|c|c|c|c|c|c|c|c|c|}
\hline \multirow{2}{*}{$\begin{array}{l}\text { U.S. Geological } \\
\text { Survey } \\
\text { streamflow- } \\
\text { gaging station }\end{array}$} & \multirow[b]{2}{*}{ Location } & \multicolumn{8}{|c|}{ Flows at indicated recurrence intervals (percent chance), $\mathrm{ft}^{3} / \mathbf{s}^{1}$} \\
\hline & & $\begin{array}{c}2 \\
(50 \%)\end{array}$ & $\begin{array}{c}5 \\
(20 \%)\end{array}$ & $\begin{array}{c}10 \\
(10 \%)\end{array}$ & $\begin{array}{c}20 \\
(5 \%)\end{array}$ & $\begin{array}{c}50 \\
(2 \%)\end{array}$ & $\begin{array}{c}100 \\
(1 \%)\end{array}$ & $\begin{array}{c}200 \\
(0.5 \%)\end{array}$ & $\begin{array}{c}500 \\
(0.2 \%)\end{array}$ \\
\hline 06934500 & Hermann, Missouri & 248,000 & 363,000 & 439,000 & 511,000 & 604,000 & 673,000 & 742,000 & 833,000 \\
\hline 06909000 & Boonville, Missouri & 203,000 & 289,000 & 352,000 & 415,000 & 503,000 & 573,000 & 648,000 & 753,000 \\
\hline 06895500 & Waverly, Missouri & 150,000 & 212,000 & 258,000 & 305,000 & 371,000 & 424,000 & 480,000 & 561,000 \\
\hline 06893000 & Kansas City, Missouri & 142,000 & 210,000 & 245,000 & 289,000 & 351,000 & 401,000 & 454,000 & 530,000 \\
\hline 06818000 & St. Joseph, Missouri & 109,000 & 147,000 & 174,000 & 199,000 & 233,000 & 261,000 & 287,000 & 324,000 \\
\hline 06813500 & $\begin{array}{l}\text { Rulo, Nebraska } \\
\quad(\text { Kansas City, USACE })^{2}\end{array}$ & 96,100 & 132,000 & 158,000 & 184,000 & 220,000 & 250,000 & 281,000 & 320,000 \\
\hline 06813500 & $\begin{array}{l}\text { Rulo, Nebraska } \\
\quad(\text { Omaha, USACE })^{2}\end{array}$ & 94,700 & 132,300 & 160,900 & 188,600 & 217,300 & 252,200 & 296,900 & 370,700 \\
\hline 06807000 & Nebraska City, Nebraska & 88,000 & 118,700 & 149,800 & 189,900 & 206,400 & 236,700 & 275,900 & 345,400 \\
\hline 06610000 & Omaha, Nebraska & 64,200 & 85,300 & 123,600 & 132,700 & 147,900 & 174,700 & 204,500 & 247,900 \\
\hline 06601200 & Decatur, Nebraska & 52,400 & 70,500 & 87,200 & 101,600 & 120,500 & 141,800 & 164,800 & 197,700 \\
\hline 06486000 & Sioux City, Iowa & 49,500 & 66,800 & 78,300 & 93,900 & 113,800 & 133,800 & 155,000 & 185,400 \\
\hline
\end{tabular}

${ }^{1}$ From U.S. Army Corps of Engineers Upper Mississippi River System Flow Frequency Study (U.S. Army Corps of Engineers, 2004d).

${ }^{2}$ Frequency analyses for the Rulo gage were completed by two offices of the U.S. Army Corps of Engineers, with slightly different results (U.S. Army Corps of Engineers, 2004d).

ered range of flows, and so provide reliable estimates of watersurface elevations at approximately each mile along the river. Local variations of hydraulics at finer scales of resolution, of course, are not present in the models. The UMRSFFS hydraulic models include the effects of levees such that flows within the levees are constricted, resulting in locally increased watersurface elevations, and flows that are greater than local levee elevations spread out, resulting in locally decreased elevations.

No hydraulic models have been developed and calibrated for more frequent flows on the entire LMOR; hence, watersurface elevations were interpolated between gages parallel to the construction reference plane to provide rough estimates of elevations for more frequent flows. We emphasize that these water-surface elevations are used as references for relative elevations; they are not used as predictors of water surfaces. All water-surface elevations were relative to the National Geodetic Vertical Datum of 1929 (NGVD 29).

We assigned water surface elevations corresponding to flood frequencies and flow exceedances to a point at every river mile along the LMOR using the USACE 1960 river mile definitions. We also assigned elevations to points placed on a 500 -m buffer on each side of the channel and to points on a line delineating the valley wall. The former were used for flow exceedance elevations and the latter for flood elevations. In each case, the points were assigned elevations corresponding to the elevations of the nearest neighbor among the river-mile points. Locations of the points were shifted along the channel buffer and the valley wall to define transects perpendicular to the channel (in the case of flow-exceedance elevations) or perpendicular to the valley (in the case of flood elevations). The intent of these adjustments was to create realistically sloping water-surface elevations. The points were then converted to a triangulated irregular network (TIN) using relevant watersurface elevations as the height source, and then gridded into 5-m cells. Long profiles of the entire LMOR study section are shown in figure 6.

\section{Land-Surface Elevations}

Land-surface elevations are used to assess how surface water interacts with the ground surface. Two sources of landsurface elevations were used in this study. The first is the National Elevation Dataset (NED; U.S. Geological Survey, 1999), which is a cell-based dataset of elevations each onethird arc-second (or about $30 \mathrm{~m}$ ). This dataset was used only for validation of regional trends since it does not have sufficient resolution to show many of the surface-topographic features relevant to this study. The data are provided using North American Datum of 1983 (NAD 83) as a horizontal reference and North American Vertical Datum of 1988 (NAVD 88) as a vertical reference. The data were converted to NVGD 29 vertical datum for comparison with other datasets using corrections obtained through the National Geodetic Survey (National Geodetic Survey, 2003). 


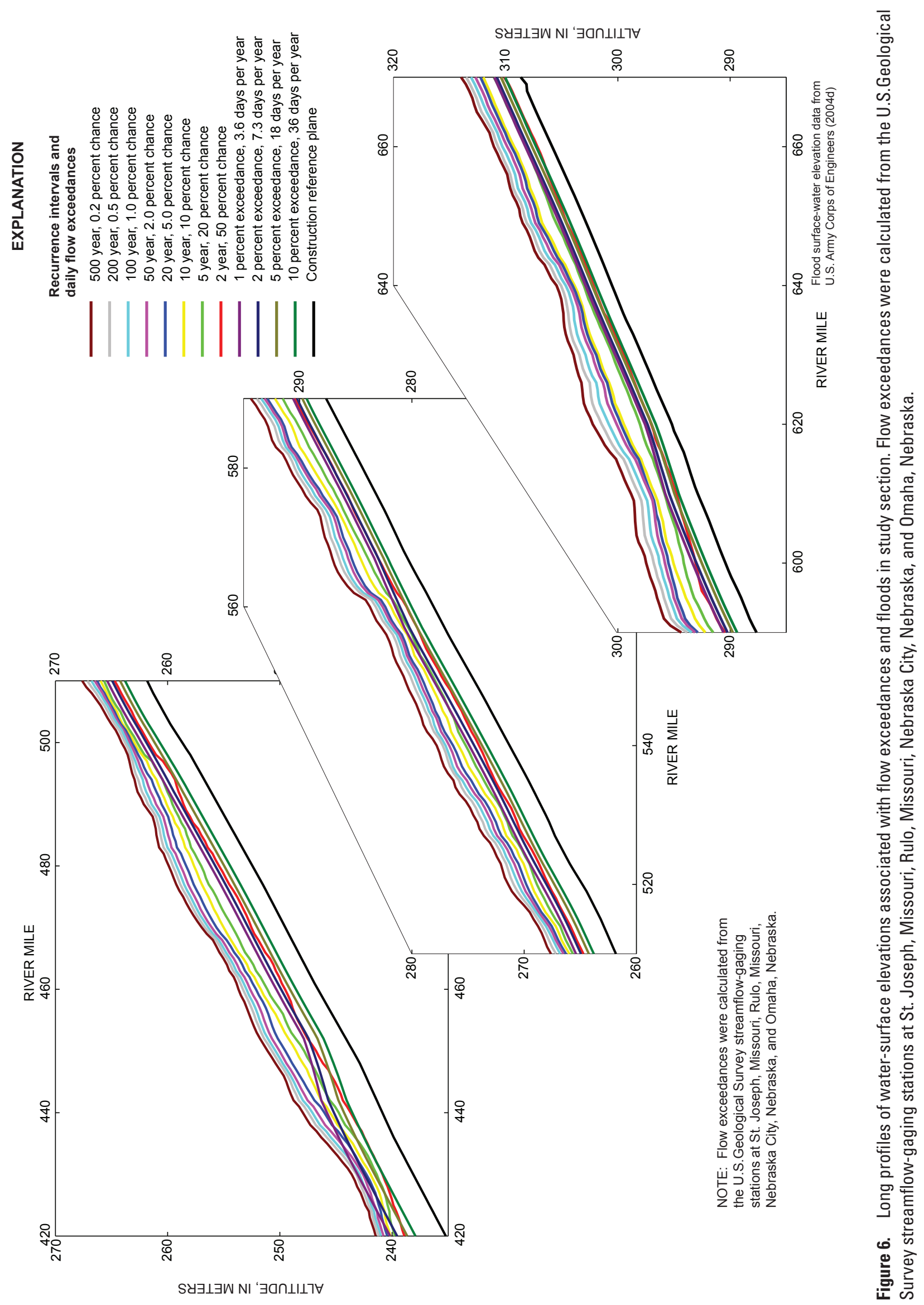


The primary land-surface elevation dataset was compiled by the USACE for the UMRSFFS. This dataset originally was compiled through photogrammetric methods that collected breaklines and mass points with a root-mean square vertical error of approximately $0.2 \mathrm{~m}$ (U.S. Army Corps of Engineers, 2004d). The land-surface dataset was supplemented with a bathymetric dataset for the Missouri River as part of the same project. Bathymetric data were collected by echosounding on lines spaced approximately $150 \mathrm{~m}$ apart with accuracies estimated at $0.15 \mathrm{~m}$. The bathymetric data were collected by the USACE during 1994 to 1998 . Because of the widely spaced cross sections and dynamic nature of channel morphology of the Missouri River, these data should be considered indicative of general channel conditions rather than relevant to contemporary, site-specific conditions.

We created a master digital elevation model from the raw data points. Channel bathymetry data were treated separately from the valley-bottom data. In the channel, we used a routine available in the Multi-dimensional Surface Water Modeling System software (McDonald and others, 2005) to interpolate and grid the data because the routine allows for streamwise interpolation, a critical approach when gridding transect data that have many points along a transect and sparse (or no) points between the transects. The streamwise interpolation and gridding produced a realistic topographic map of the channel, thalweg, banks, and bars. Navigation structures (wing dikes) are not well represented in the dataset because they were not captured at the same resolution as the bathymetric data collection. After streamwise interpolation, we gridded the channel to 5-m cells.

We processed the valley-bottom data by treating breaklines (lines of high-density data collected along linear structures such as levees, banks, and roads) and mass points (points randomly or systematically collected in open areas) separately in a TIN. The TIN step allowed us to improve the gridding process by incorporating breaklines. The TIN subsequently was gridded to 5-m cells. A close up of a small part of the finished gridded product is shown in figure 7 .

\section{Soil Drainage Classes}

The water-retention capacity of the landscape relates to the hydraulic conductivity of the soil and surficial geologic materials as well as topographic characteristics that can enhance water access or retard water drainage. We used soil-drainage class as a measure of the ability of the soil to retain water during saturated conditions. Drainage classes conceptually integrate saturated hydraulic conductivity of the soil and underlying geologic materials, and to some extent, contain information related to surface topography (Soil Survey Staff, 1993). Seven soil-drainage classes were extracted from the Natural Resources Conservation Service (NRCS) Soil Survey Geographic (SSURGO) database maps (fig. 8) for each county within the study area (Natural Resources Conservation Service, 2003-2006).
The soils databases used included data from 17 counties in 4 states. Because these counties were mapped over a number of years, by different personnel, and with different specifications, the map units do not always match at county boundaries. Moreover, the spatial detail of the maps varies considerably from county to county. Therefore, to simplify the analysis and to minimize the mismatches among counties, we combined the seven NRCS drainage classes into four retention classes (table 2). The "other" drainage class includes urban areas and water bodies.

\section{Integration of Topography and Drainage Classes}

The goal of the LCPI is to integrate relevant measures of water, land-surface elevations, and soil materials to define units that provide a classification with useful information for land-use decisions. The first step is to intersect water-surface and land-surface elevations.

It should be emphasized that the purpose of intersecting water-surface and land-surface elevations is to provide references for relative wetness, not to predict flooded areas. The water-surface elevations indicated by interpolating flows with similar exceedances between gage sites do not account for variations in hydraulic roughness, channel morphology, or channel slope that would strongly affect local stage. Moreover, although the water-surface elevations determined by hydraulic models for the UMRSFFS account for roughness, morphology, and slope, the maps do not take into account whether or not the water has an overland flow path to all areas in the valley bottom at the modeled water-surface elevation or lower. Hence, the UMRSFFS water-surface elevations do not necessarily extend to all the indicated polygons; there may be natural topographic or engineered barriers such as roads or levees (fig. 9). For flows that are overbank but lower than the levees, the mapped polygons may over-estimate ("overmap") potential area that would be flooded by overbank flows, even without levees. These areas do, however, indicate the areas of the valley bottom that would be affected by impeded interior drainage or ground-water drainage if water levels in the channel were held against the levees for long durations. For the purposes of the LCPI, these areas are treated as having the same wetness potential as those at the same elevations on the channel side of the levee. Except in urban areas, the 100and 500-year elevations would overtop all levees, and since the UMRSFFS models explicitly included these levees, the mapped flooded areas are consistent with model predictions.

Areas of wetness classes were calculated on a cell-bycell basis by subtracting the land-surface elevation grid from the water-surface elevation grids. To limit the number of classes, we delineated four wetness potential classes (table 2), corresponding to: flows up to the 2-year flood, between the 2 - and 10-year flood, between the 10- and 500-year flood, and less frequently flooded than once every 500 years (fig. 10). These divisions are somewhat arbitrary and different divisions could be defined with the available data. We chose not to use 


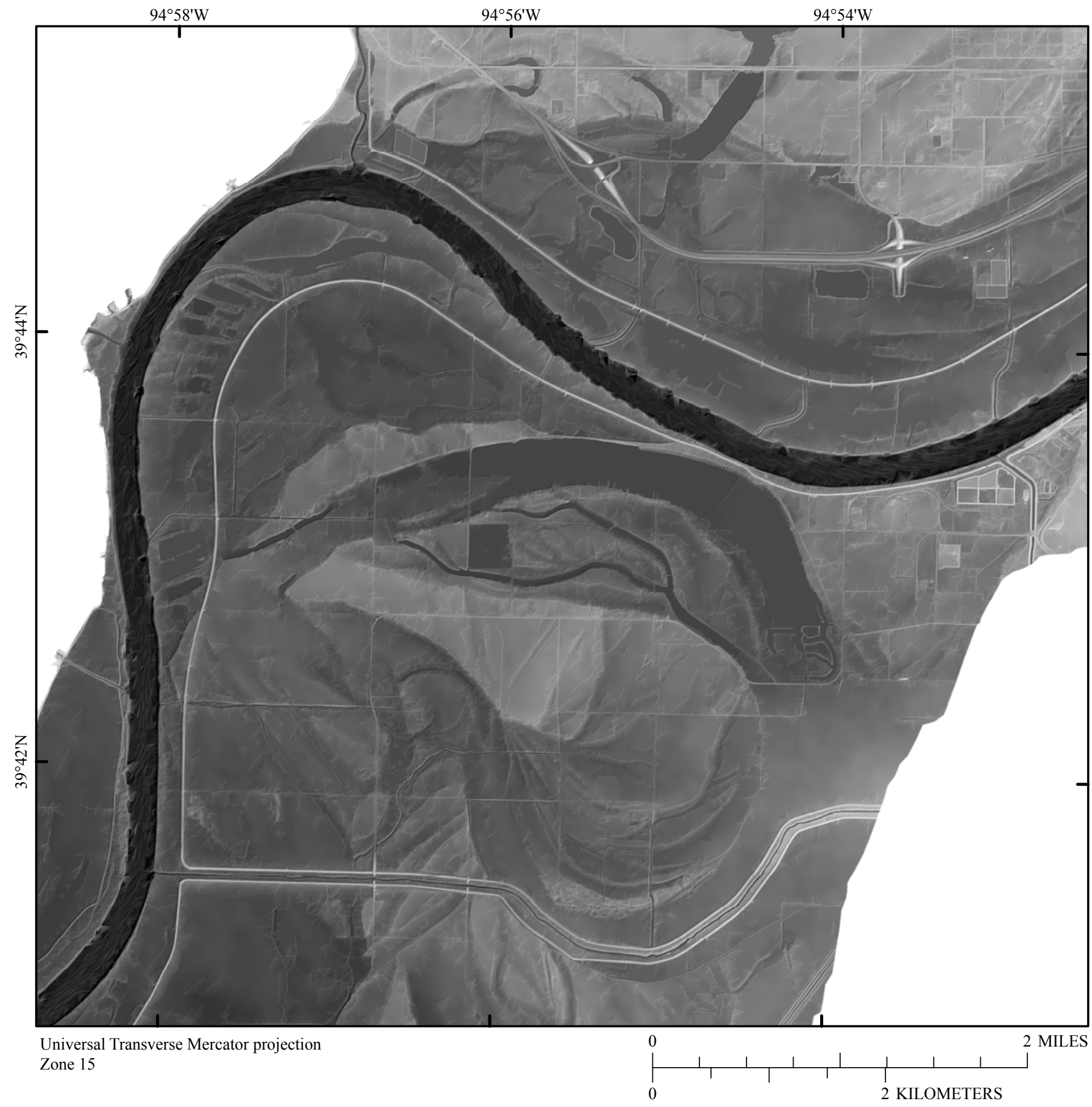

EXPLANATION

Elevation, in meters

Figure 7. Part of the Lower Missouri River valley bottom near St. Joseph, Missouri, showing the topographic detail available from the elevation dataset. 


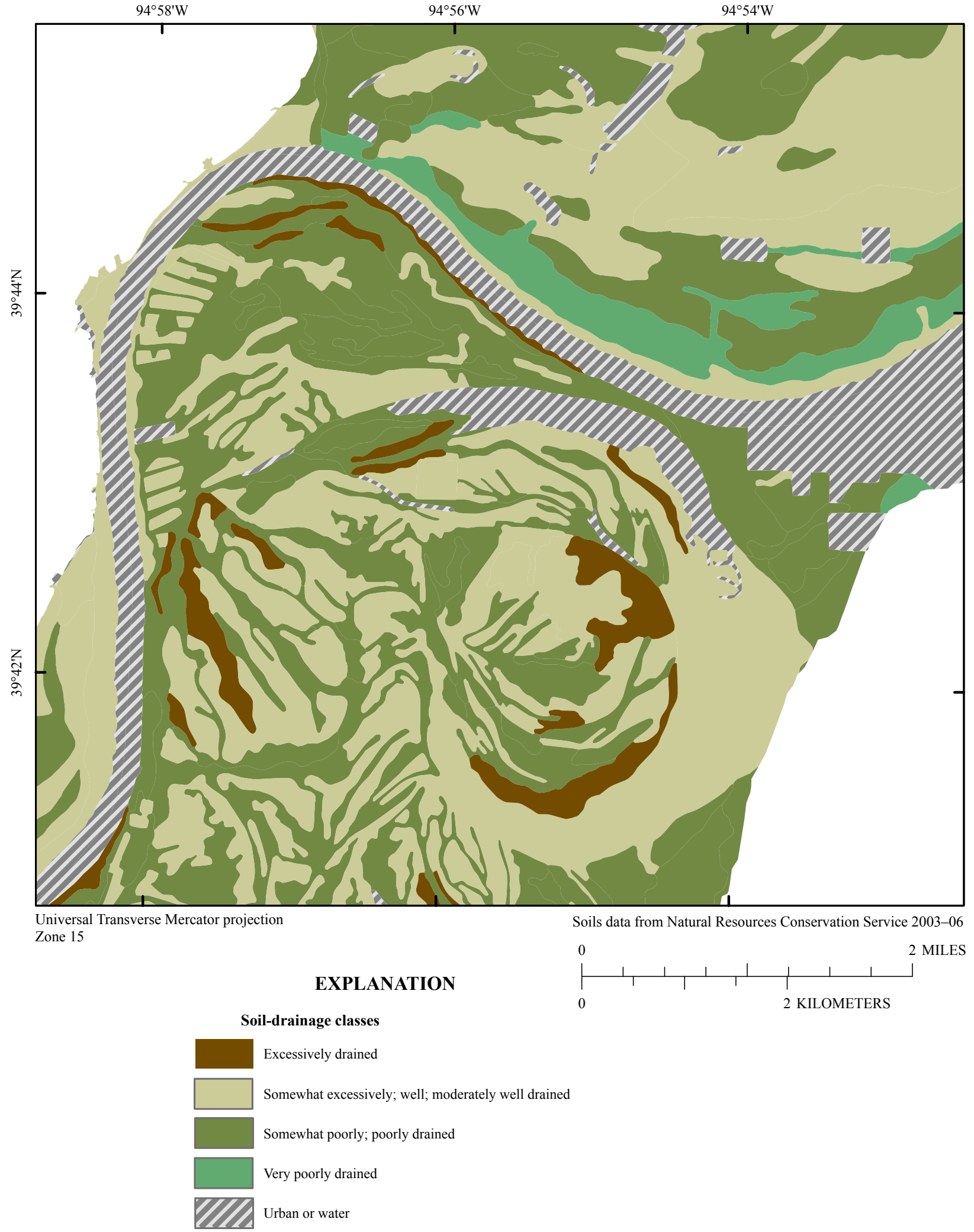

Figure 8. Soil-drainage classes of a part of the Lower Missouri River valley bottom near St. Joseph, Missouri. 
Table 2. Aggregation of wetness and soil drainage classes into tentative Land Capability Potential Index (LCPI) classes.

[LCPI, Land-Capability Potential Index; NRCS, Natural Resources Conservation Service; <, less than; >, greater than]

\begin{tabular}{|c|c|c|c|c|c|}
\hline $\begin{array}{l}\text { LCPI } \\
\text { retention } \\
\text { classes }\end{array}$ & $\begin{array}{l}\text { NRCS } \\
\text { soil drainage } \\
\text { classes }\end{array}$ & \multicolumn{4}{|c|}{ Wetness composite classes } \\
\hline $\begin{array}{l}\text { Strongly } \\
\text { retentive }\end{array}$ & $\begin{array}{c}\text { Very poorly } \\
\text { drained }\end{array}$ & $\begin{array}{l}\text { Frequently flooded, } \\
\text { strongly retentive } \\
\left(\mathrm{F}^{1} \mathrm{~S}^{2}\right)\end{array}$ & $\begin{array}{l}\text { Moderately flooded, } \\
\text { strongly retentive } \\
\text { (MS) }\end{array}$ & $\begin{array}{l}\text { Infrequently flooded, } \\
\text { strongly retentive } \\
\text { (IS) }\end{array}$ & $\begin{array}{l}\text { Rarely flooded, } \\
\text { strongly retentive } \\
\text { (RS) }\end{array}$ \\
\hline $\begin{array}{l}\text { Moderately } \\
\text { retentive }\end{array}$ & $\begin{array}{l}\text { Somewhat poorly } \\
\text { and poorly } \\
\text { drained }\end{array}$ & $\begin{array}{l}\text { Frequently flooded, } \\
\text { moderately } \\
\text { retentive } \\
(\mathrm{FM})\end{array}$ & $\begin{array}{l}\text { Moderately flooded, } \\
\text { moderately } \\
\text { retentive } \\
(\mathrm{MM})\end{array}$ & $\begin{array}{l}\text { Infrequently flooded, } \\
\text { moderately } \\
\text { retentive } \\
\text { (IM) }\end{array}$ & $\begin{array}{l}\text { Rarely flooded, } \\
\text { moderately } \\
\text { retentive } \\
(\mathrm{RM})\end{array}$ \\
\hline Poorly retentive & $\begin{array}{l}\text { Somewhat exces- } \\
\text { sively, well, and } \\
\text { moderately well } \\
\text { drained }\end{array}$ & $\begin{array}{l}\text { Frequenty flooded, } \\
\text { poorly retentive } \\
\text { (FP) }\end{array}$ & $\begin{array}{l}\text { Moderately flooded, } \\
\text { poorly retentive } \\
\text { (MP) }\end{array}$ & $\begin{array}{l}\text { Infrequently flooded, } \\
\text { poorly retentive } \\
\text { (IP) }\end{array}$ & $\begin{array}{l}\text { Rarely flooded, } \\
\text { poorly retentive } \\
\text { (RP) }\end{array}$ \\
\hline Non-retentive & $\begin{array}{c}\text { Excessively } \\
\text { drained }\end{array}$ & $\begin{array}{l}\text { Frequently flooded, } \\
\text { non-retentive } \\
\text { (FN) }\end{array}$ & $\begin{array}{l}\text { Moderately flooded, } \\
\text { non-retentive } \\
(\mathrm{MN})\end{array}$ & $\begin{array}{l}\text { Infrequently flooded, } \\
\text { non-retentive } \\
\text { (IN) }\end{array}$ & $\begin{array}{l}\text { Rarely flooded, } \\
\text { non-retentive } \\
\text { (RN) }\end{array}$ \\
\hline
\end{tabular}

\footnotetext{
${ }^{1}$ The first letter of the designation for composite classes refers to wetness class.

${ }^{2}$ The second letter refers to relative retention class.
}

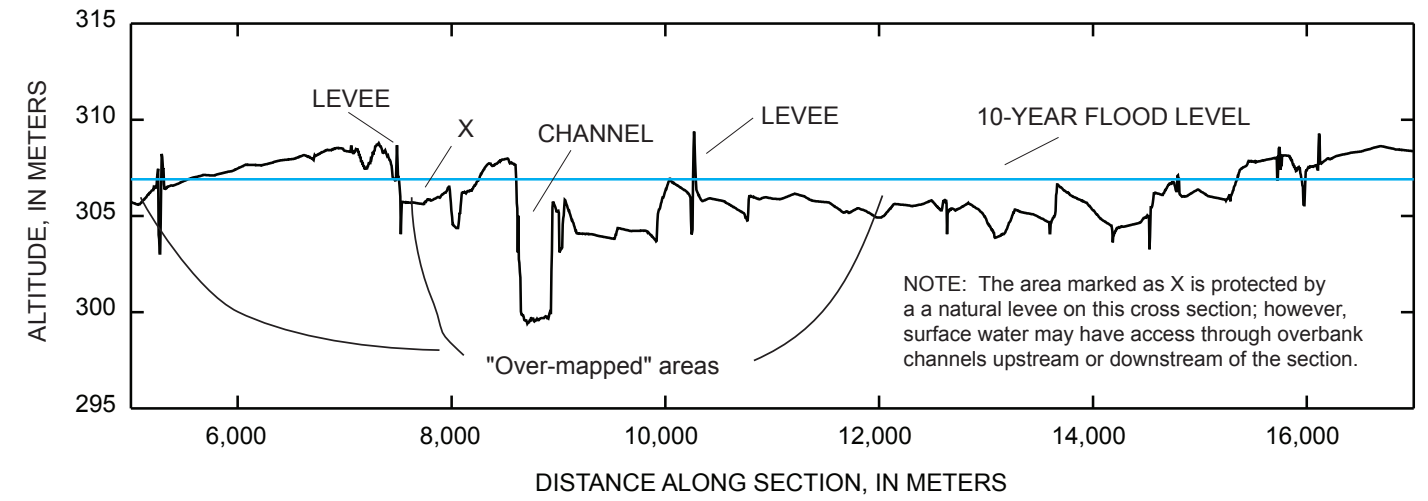

Figure 9. An example illustrating the potential effect of "overmapping" of flood areas by extrapolating flood levels across the valley bottom. The area marked as $X$ is protected by a natural levee on this cross section; however, surface water may have access through overbank channels upstream or downstream of the section. 

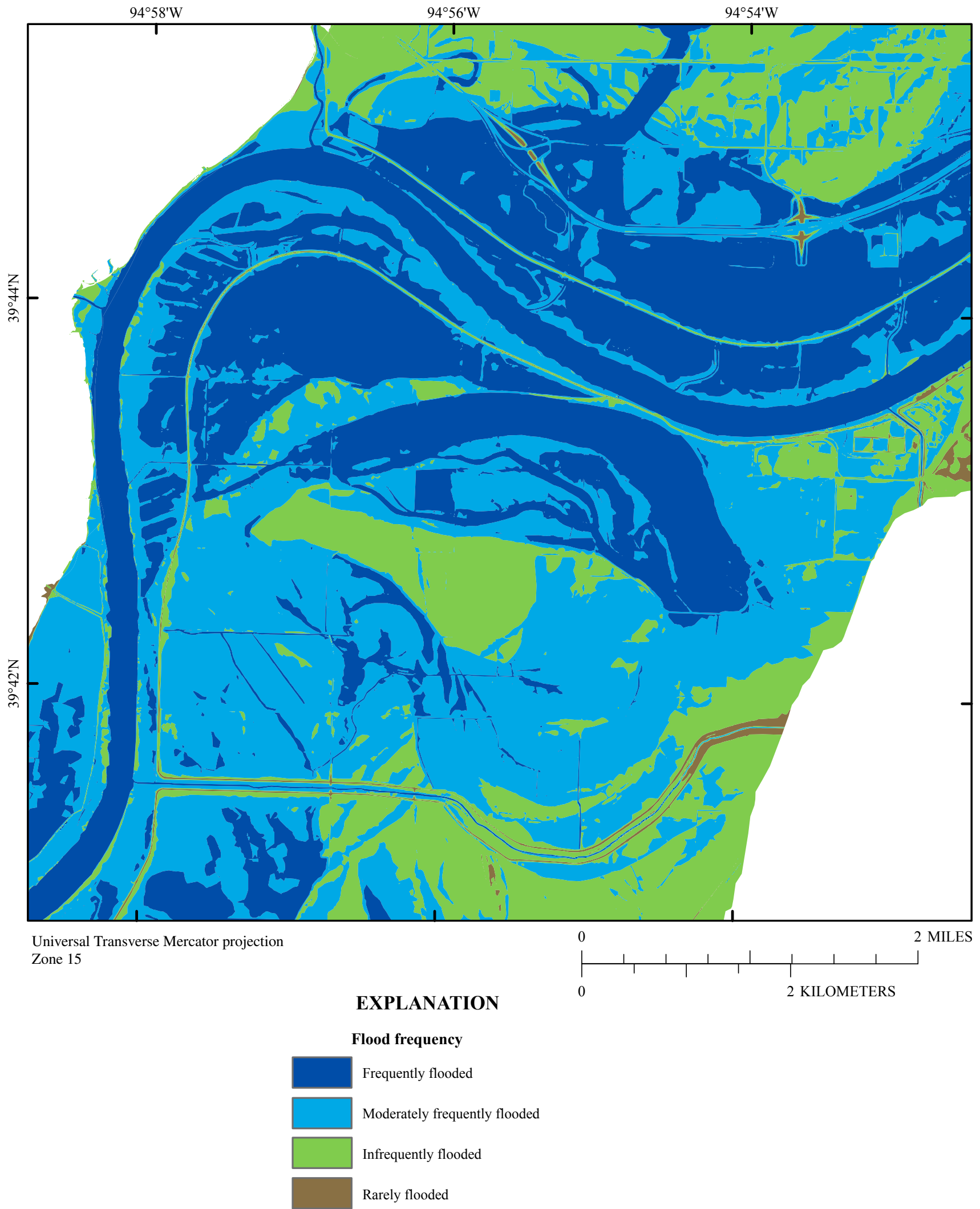

Figure 10. Relative flood frequency of a part of the Lower Missouri River valley bottom near St. Joseph, Missouri, estimated from intersecting water-surface profiles with valley-bottom elevations. 
water-surface elevations calculated from flow exceedances at the streamflow-gaging stations because of the potential errors associated with the assumptions of linear interpolations between stations, and because of the large overlap between elevations calculated for relatively low exceedances $(1,2$, and 5 percent) and flood probabilities (fig. 6). This overlap arises in part from the fact that floods on large rivers typically have long durations. Therefore, a single flood that would be used in an annual flood series for flood-frequency calculation, could inundate a flood plain for weeks to months, thereby increasing the calculated exceedance (number of days equaled or exceeded) for that flow.

In addition to intersecting the water-surface elevation grids with the high-resolution land-surface elevation grids, we also intersected the water surfaces with the lower resolution NED grid for validation. The NED grid does not capture Missouri River bathymetry or much of the fine-scale topographic variability in the valley bottom, but it is useful to validate general patterns of relative wetness.

The 4 wetness classes were joined with the 4 retention classes to define a set of 16 composite classes as the initial LCPI classification (table 2; fig. 11).

\section{Terrain Mapping Assessment}

A final complementary assessment was developed by processing topographic data to define terrain units. Terrain units are based on relative topographic position of points in the landscape. Our approach is an application of the benthic terrain mapping approach developed by Lundblad and others (2006). This approach classifies the landscape into convex-up areas (crests, such as natural bar forms, flood-plain ridges, levees, and road embankments), concave-up areas (depressions, such as river channels, flood-plain swales, and drainage ditches), and areas without appreciable concavity or convexity. Areas lacking topographic variability are classified according to whether they are sloping or flat, based on applying a threshold slope angle.

\section{Results}

The regional spatial distribution of wetness is extremely non-uniform (fig. 12). Illustrated using 2-year flow elevations as a reference, the distribution shows areas that are distinctly wetter in the center of the study area compared to the northern and southern ends. This is consistent with the understanding of the spatial distribution of channel aggradation (fig. 3) from analysis of trends in streamflow-gaging station records (U.S. Army Corps of Engineers, 2004b). Another area of greater wetness downstream from St. Joseph may indicate another discrete area of channel aggradation.

At a much finer scale, the 16 LCPI classes used in the detailed analysis define a complex mosaic of patches with varying land-capability potential (fig. 11). These classes delin- eate areas with common wetness and soil drainage characteristics, the fundamental controls on the template of river-corridor ecosystems and land use. The maps do not, however, account for manmade structures such as roadways, ditches, or levees that can mitigate the natural potential.

Two additional methods to analyze landscape elevation relations also were explored. In the first, elevations of the valley bottom were calculated relative to the Construction Reference Plane (CRP; fig. 13). The CRP is defined as a plane that slopes in a streamwise direction at a water-surface elevation equal to the flow equaled or exceeded 75 percent of the time. It is used by the USACE as a low-flow construction reference elevation. Rendering of elevations relative to CRP, using a continuous range of colors, indicates relative wetness of a site without implication of flooding frequency.

Valley-bottom elevation data also can be analyzed in terms of terrain classes based on topographic characteristics such as relative concavity or convexity of landforms and slope. In the example shown in figure 14, we used classification parameters that work well within channels rather than optimizing parameters for valley-bottom topography. Nevertheless, the process delineated parts of the valley bottom landscape that clearly differ with respect to convexity and concavity, and that may have substantially different localized hydrologic and edaphic conditions. Additional calibration may be needed to optimize terrain classification methods to delineate units for particular purposes. Terrain classes also could be combined with relative wetness and soils classes to create complex indices.

\section{Summary and Conclusions}

The Land Capability Potential Index (LCPI) was constructed from the integration of hydrology, hydraulics, landsurface elevations, and soil drainage-class datasets in a section of the Lower Missouri River (LMOR), river miles 423-670. The LCPI estimates relative wetness based on intersecting water-surface elevations, interpolated from measurements or calculated from hydraulic models, with the land surface. The potential for wet areas to retain or drain water is added in with soil-drainage classes that are determined from permeability of surface soils and subsurface geologic strata. Terrain mapping that delineates areas with convex, concave, and flat parts of the landscape provides another means to assess tendency of landscape patches to hold surface water.

The LCPI is a relatively coarse index intended to delineate broad land capability classes in the LMOR valley. The index integrates fundamental factors that determine suitability of land for various uses, and may provide a useful mechanism to guide land-management decisions. For example, the LCPI could provide a template for prioritizing acquisition of conservation land or for enrollment of lands into wetland reserve programs. The calibration of the LCPI presented here is based on our judgment of dominant modes of wetness and 


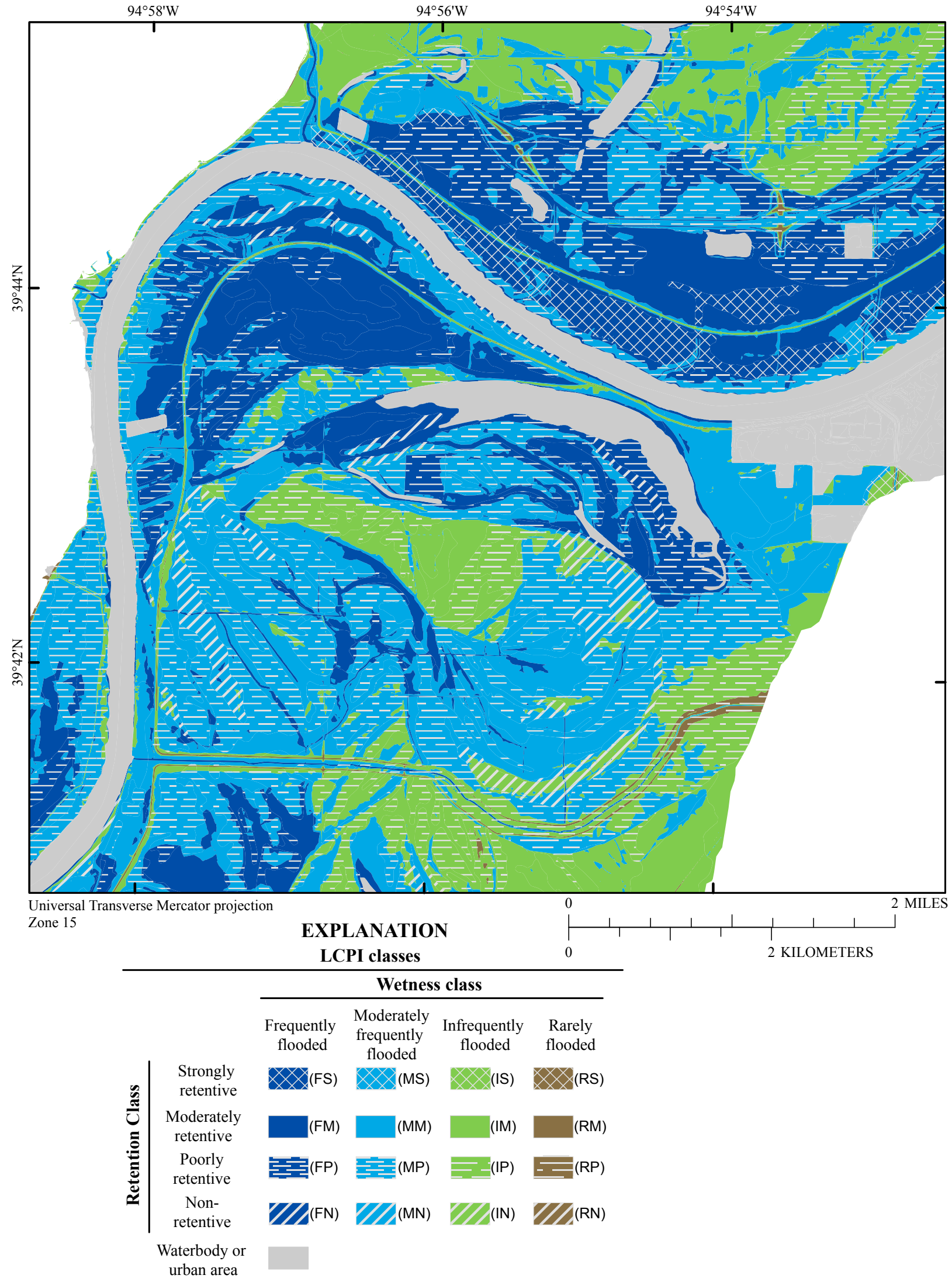

Figure 11. Land Capability Potential Index classes calculated from integrating wetness and retention classes, for a part of the Lower Missouri River valley bottom near St. Joseph, Missouri. 


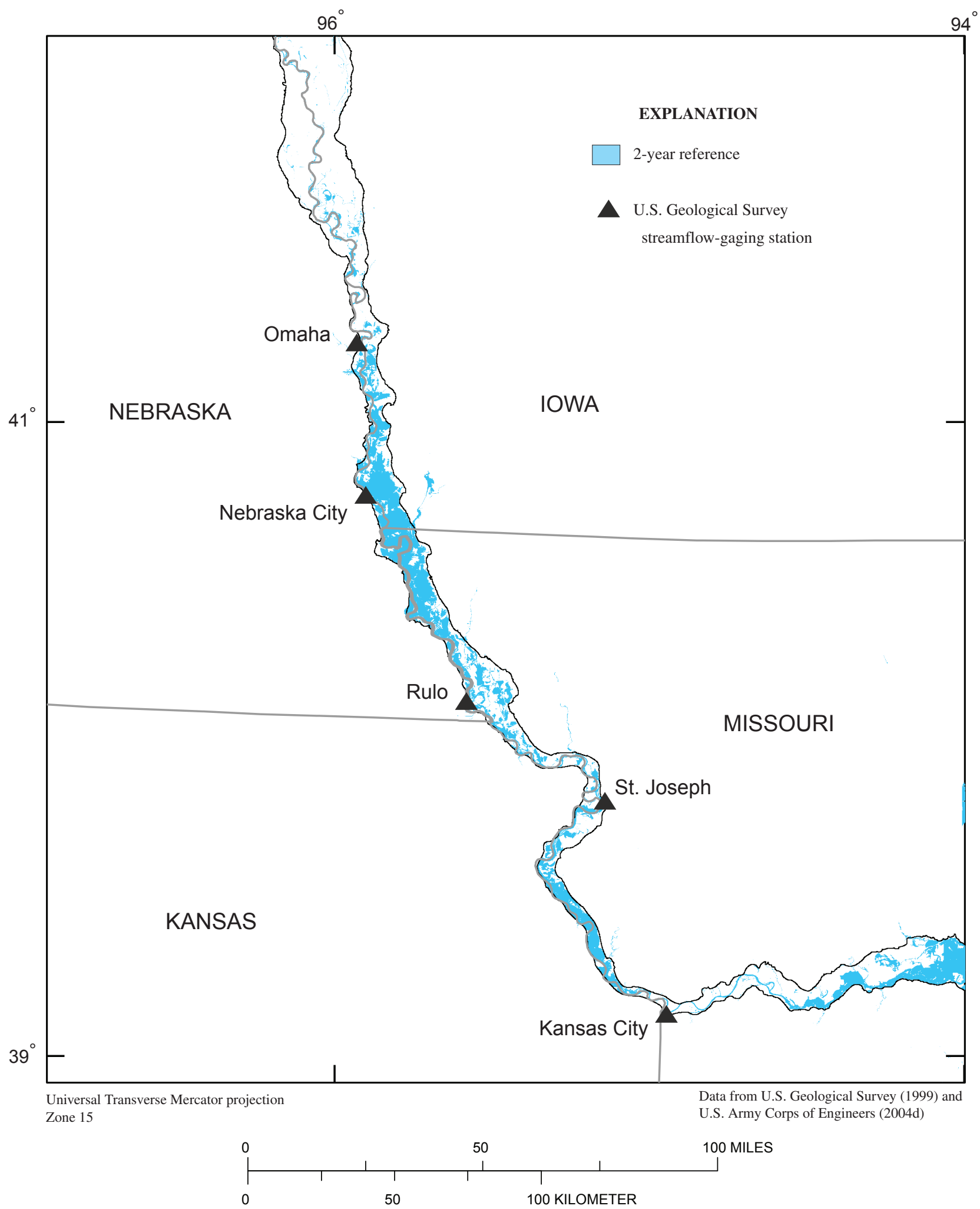

Figure 12. Two-year flooding reference elevation showing regional variation of wetness potential as a result of channel aggradation and degradation. Map is based on the NED 1/3 arc-second elevation database (U.S. Geological Survey, 1999) and water-surface elevations from the Upper Mississippi River Flow Frequency Study (U.S. Army Corps of Engineers, 2004d). 


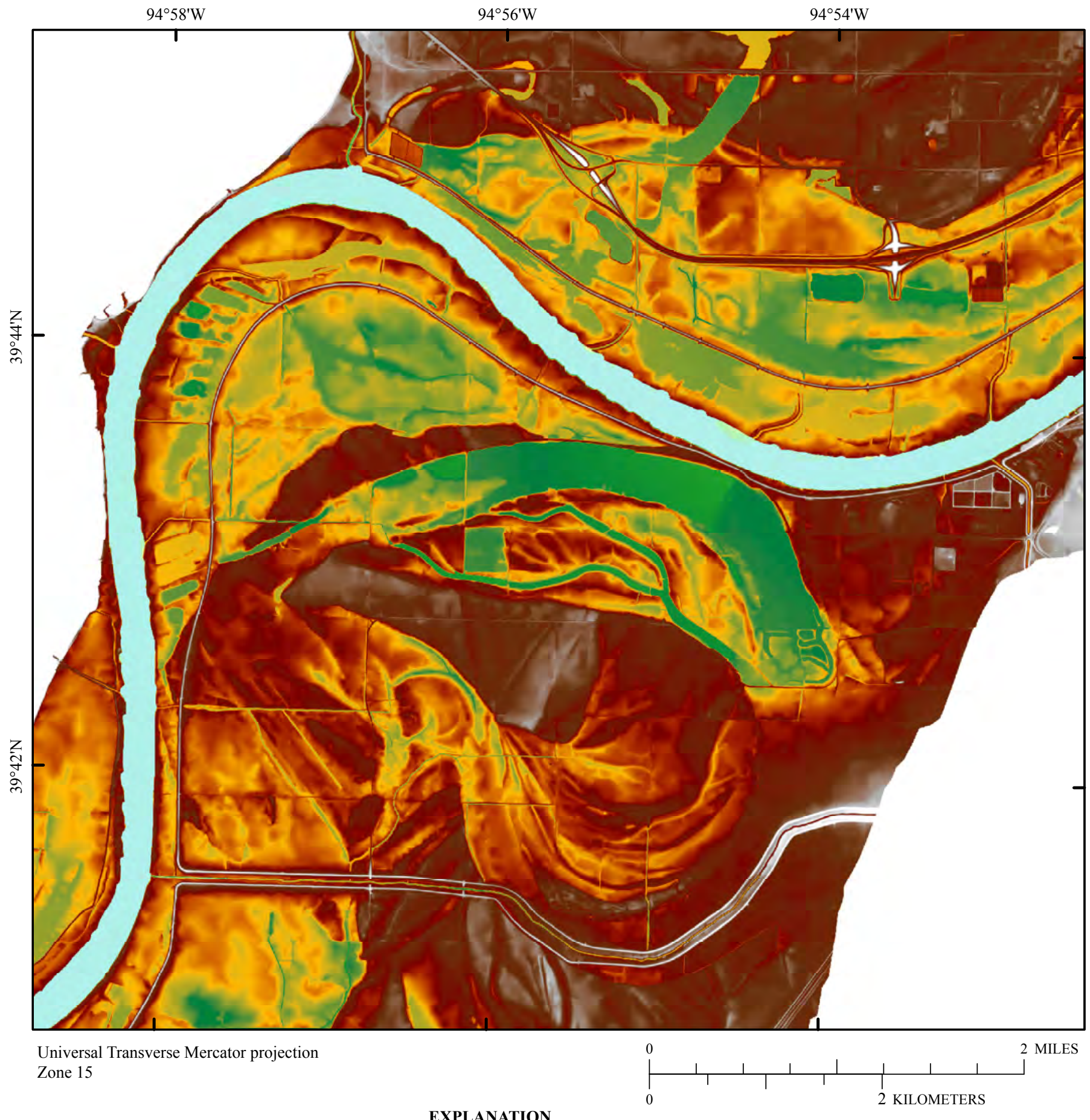

Elevation relative to $\mathrm{CRP}$

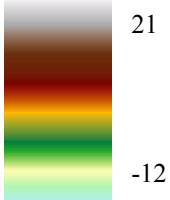

NOTE: Large numbers are due to inclusion of some bluff elevations in the grid. Negative numbers in the channel are areas below CRP.

Figure 13. Land-surface elevation relative to the Construction Reference Plane (CRP). Large numbers are due to inclusion of some bluff elevations in the grid. Negative numbers in the channel are areas below CRP. 


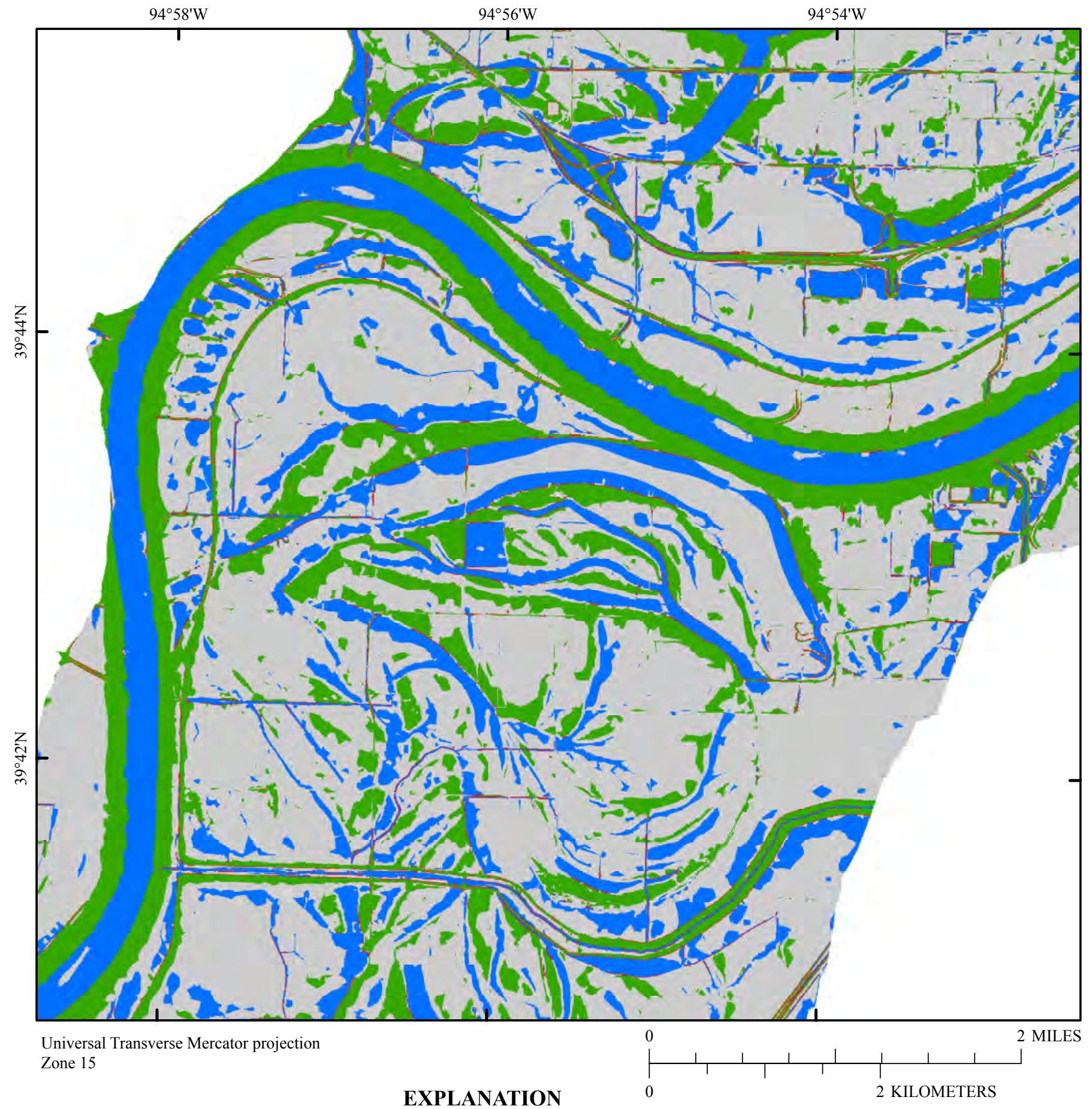

EXPLANATHON

Terrain classes

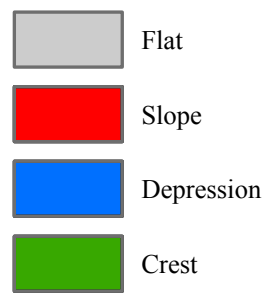

Figure 14. Terrain classes for a part of the Lower Missouri River valley bottom near St. Joseph, Missouri. 
retention that interact to form the landscape mosaic. Custom calibrations for specific purposes could be generated by selecting different flooding classes or soil drainage classes, or by incorporating other datasets such as existing land cover.

\section{References Cited}

Holbrook, J., Kliem, G., Nzewunwah, C., Jobe, Z., and Goble, R., 2006, Surficial alluvium and topography of the Overton Bottom North Unit, Big Muddy National Fish and Wildlife Refuge in the Missouri River valley and its potential influence on environmental management, in Jacobson, R.B., ed., Science to support adaptive habitat management, Overton Bottoms North Unit, Big Muddy National Fish and Wildlife Refuge, Missouri: U.S. Geological Survey Scientific Investigations Report 2006-5086, p. 17-32.

Jacobson, R.B., ed., 2006, Science to support adaptive habitat management, Overton Bottoms North Unit, Big Muddy Fish and Wildlife Refuge, Missouri: U.S. Geological Survey Scientific Investigations Report 2006-5086, 116 p.

Jacobson, R.B., and Galat, D.L., 2006, Flow and form in rehabilitation of large-river ecosystems: An example from the Lower Missouri River: Geomorphology, v. 77, no. 3-4, p. 249-269.

Lundblad, E.R., Wright, D.J., Miller, J., Larkin, E.M., Rinehart, R., Naar, D.F., Donahue, B.T., Anderson, S.M., and Battista, T., 2006, A benthic terrain classification scheme for American Samoa: Marine Geodesy, v. 29, no. 2, p. 89-111.

McDonald, R.R., Nelson, J.M., and Bennett, J.P., 2005, Multidimensional surface-water modeling system user's guide: U.S. Geological Survey Techniques and Methods 6-B2, $136 \mathrm{p}$.

National Geodetic Survey, 2003, VERTCON: available at: URL http://www.ngs.noaa.gov/pc_proc/verton/index.shtml.

Natural Resources Conservation Service, 2003-2006, Soil Survey Geographic (SSURGO) database, U.S. Department of Agriculture, Natural Resources Conservation Service, available at: URL http://SoilDataMart.nrcs.usda.gov/.
Pinter, N., Wlosinksi, J.H., and Heine, R.A., 2002, The case for utilization of stage data in flood-frequency analysis: Preliminary results from the Middle Mississippi and Lower Missouri River: Hydrologic Science and Technology Journal, v. 18, no. 1-4, p. 173-185.

Soil Survey Staff, 1993, Soil survey manual: Washington, D.C., United States Department of Agriculture, Soil Conservation Service, Agricultural Handbook No. 18, available at: URL http://soils.usda.gov/technical/manual/.

U.S. Army Corps of Engineers, 1996, Missouri River Gavins Point dam degradation trends study: Omaha, Nebr., U.S. Army Corps of Engineers, Northwestern Division, Reservoir Control Center Technical Report A04, 43 p.

U.S. Army Corps of Engineers, 1998, Reservoir regulation studies-Daily routing model studies, master water control manual Missouri River review and update study, v. 2A: U.S. Army Corps of Engineers, Northwest Division.

U.S. Army Corps of Engineers, 2004a, Missouri River Bank Stabilization and Navigation Project, Fish and Wildlife Mitigation Project, annual implementation report 2004: Omaha, Nebr. and Kansas City, Mo., U.S. Army Corps of Engineers, 63 p.

U.S. Army Corps of Engineers, 2004b, Missouri River Stage Trends: Omaha, Nebr., U.S. Army Corps of Engineers, Northwestern Division, Reservoir Control Center Technical Report A04, 43 p.

U.S. Army Corps of Engineers, 2004c, Summary Missouri River final environmental impact statement-Master water control manual review and update: Portland, Ore., U.S. Army Corps of Engineers, Northwest Division, 28 p.

U.S. Army Corps of Engineers, 2004d, Upper Mississippi River system flow frequency study: Rock Island, Ill., U.S. Army Corps of Engineers, 33 p.

U.S. Fish and Wildlife Service, 2003, Amendment to the 2000 Biological Opinion on the operation of the Missouri River main stem reservoir system, operation and maintenance of the Missouri River bank stabilization and navigation project, and operation of the Kansas River reservoir system: Minneapolis, Minn., U.S. Fish and Wildlife Service, 308 p.

U.S. Geological Survey, 1999, National elevation dataset: U.S. Geological Survey, available at: URL http://gisdata.usgs. net/ned/. 
Publishing support provided by:

Rolla Publishing Service Center

For more information concerning this publication, contact: Director, USGS Columbia Environmental Research Center 4200 New Haven Road

Columbia, M0 65201

(573) 875-5399

Or visit the Columbia Environmental Research Center Web site at: http://www.cerc.usgs.gov 

